\title{
AN ANALYSIS OF MORAL VALUE IN SHORT STORY "THE LAST LEAF" BY O HENRY
}

\author{
Syahada Nurul Ummah, Eripuddin, Pipit Rahayu \\ Eripuddin85@gmail.com,darariau2010@gmail.com
}

\begin{abstract}
English Study Program, Faculty of Teacher Training and Education, University of Pasir Pengaraian
\end{abstract}

\begin{abstract}
This research discussed about the moral values as found out in the last leaf short story. Moral values were found out by using sociological theory. This research used method descriptive qualitative. This instrument used was the short story of The Last Leaf. The researcher also used other information about moral values. Researchers also use the theory of moral values in order to better know what moral values are contained in the short story of The Last Leaf. Based on the sociological approach, there are three perspectives: functional perspective, symbol perspective, conflict perspective. After analyzing the researcher found some moral values, namely Tolerance, Fairness, Belief, Kind-hearted, honesty, and responsibility.
\end{abstract}

Keywords: Sociological theory, Moral value, The Last Leaf short story

\section{INTRODUCTION}

Literature is generally divided into three groups; respectively prose, drama and poetry (Risdianto, 2011:5). Literature is used to describe anything from creative writing to more technical or scientific works. The term is most commonly used to refer to works of the creative imagination, including works of poetry, drama, fiction, and nonfiction. Literature has an important role in human life; it has given much of entertainment, inspiration, motivation, information, and etc.
Short story is a short work of fiction. Fiction is process writing about imagined evens and character. Short story is one of the literature forms that are a work of fiction that is usually written in prose, often in narrative format.

Moral is a word derives from Latin "mos" (Moris) means custom, habitual, values, and role of life (Bertens, 2005: 4). He stated that one perspective on the development of morality was that it entailed the construction of judgments about justice, equality, and cooperation. In line with 
his theoretical general approach, Piaget proposed that children's moral development stems from their reciprocal interactions with other including adult and peers.

The Last Leaf, short story by O. Henry, published in 1907 in his collection The Trimmed Lamp and Other Stories. "The Last Leaf" concerns Johnsy, a poor young woman who is seriously ill with pneumonia. She believes that when the ivy vine on the wall outside her window loses all its leaves, she will also die. Her neighbor Behrman, an artist, tricks her by painting a leaf on the wall. Johnsy recovers, but (in a twist typical of $\mathrm{O}$. Henry) Behrman, who caught pneumonia while painting the leaf, dies.

Based on the researcher's when analyze find out the moral values that are contained the short story. The researcher hope the reader more learning moral values and apply it in their daily life. The researcher difficulties find strategy or the theory to find the moral values in short story. This is what makes the researcher interested to analyze.

In this study, researchers analyzed the short story The Last Leaf written by O Henry. This is one of the short stories about three friends of artists who have different characteristics and one of them is an old Behrman who always sacrifices for his friend.

In addition, researchers want to know the moral value of short stories and their application in our lives. Therefore, researchers are interested in conducting a study entitled "An

\section{Analysis of Moral Values in Short} Story" The Last Leaf "by O Henry".

Purpose of the Research

Concerning to the previous problem, the purpose of the research uses to find out the moral value in short story The Last Leaf.

\section{REVIEW OF RELATED LITERATURE}

\section{The Nature of Moral Values}

According to Baguswaluyo (2007: 28), moral values are standards or principles in judging conducts or behavior. Bagus, by borrowing Stanton's opinion, says that moral values are the same in every society, since the moral values are influenced by the culture of group or society. Moral value, in this case, actually appears by the long process through the emergence of any society in running social activity. In the society, the people interact to one another. That creates norm and value of the society, then from the norm and value, the moral value based on their agreement will seems by itself.

Jacobs (2002:4) said that moral theories concerns about practice, about what people should do. They often make specific claims about which duties take precedence over others when there are conflicts. They make claims about what is morally required and what is prohibited. However, when people reflect on the theories themselves people encounter many issues that do not directly concern what people should do or how people should judge acts or 
agents. People may find that a theory presupposes that moral value is objective. It may hold that moral value is completely independent of the desires and interest people happen to have.

According to Schwartz and Boenke (2004:230-255), moral as relating to dealing with or capable of making the distinction between right or wrong conduct principles, standards habits with respect to right or wrong in conduct. Values as the social principles, goals or standards held or accepted by an individual, a class, a society, etc. In short, moral value is the relation of belief, behavior and attitude of each individual.

Moral is used to determine the boundary of a trait, temperament, opinions or actions worth saying right, wrong, good and bad (Nurgiyantoro, 2010: 320). According to Kenny (In Nurgiyantoro, 2010:320) moral as well as a theme, in terms of the content of literary works dichotomy forms, is an element of the content. It is something to be conveyed by the author to the reader.

There are some kinds of moral values that were argued by Harris (2010) such as:

\section{a. Tolerance}

Tolerance is willingness to accept behavior and beliefs which are different from one and other, although you might not agree with or approve of them (Walter, 2008). Harris (2010:33) argued that there are very practical concerns that follow from the glib idea that anyone is free to value anything. The most consequential being that is precisely what allows highly educated, secular, and otherwise well-intentioned people to pause thoughtfully, and often interminably, before condemning practices. Thus, everyone sometimes needs to understand other different belief and behavior.

\section{b. Fairness \\ According to Walter (2008)} Fairness is defined as the quality of treating people equally or in a way that is right or reasonable. Be fair is being fully separable from human well-being, we are faced with the prospect of there being morally "right" actions and social system that are, on balance, detrimental to the welfare of everyone affected by them (Harris, 2010:55). To simply bite the bullet on this point, as Rawls (in Harris, 2010:55) states "There is no reason to think that just institutions will maximize the good".

\section{c. Belief}

Belief is a state or habit of mind in which trust, confidence, reliance, is place in some person or thing. Belief is something believed, statement or body of statement held by the advocates of any class of views; conviction of the truth of some statement or the reality of some being or phenomenon, especially when based on an examination of the ground for accepting it as true or real. (Webster, 1981: 200)

\section{d. Kind-hearted}

Kind is the equivalent of what has been offered or received. Kind is applying more often to the disposition to sympathy and helpfulness. Kindly is 
stressing more the expression of the sympathetic, helpful nature, mood or impulse (a kind person with a kindly interest in the problem of other). Kindhearted is having sympathetic nature: Humane, compassionate. Kindheartedness is the quality or state of being kindhearted (Webster, 1981: 1243).

\section{e. Honesty}

Honesty is estimable character; fairness and straight forwardness of conduct or adherence to the fact. Honesty is freedom from subterfuge or duplicity, truthfulness, and sincerity (Webster, 1981: 1086).

\section{f. Responsibility}

Being responsible is to have control and authority over something or someone and the duty of taking care of it or them (Walter, 2008).

\section{Theories in Analyzing the Moral Value}

The Sociological Theory

Theories in sociology provide us with different perspectives with which to view our social world. A perspective is simply a way of looking at the world. A theory is a set of interrelated propositions or principles designed to answer a question or explain a particular phenomenon; it provides us with a perspective. Sociological theories help us to explain and predict the social world in which we live (Mooney, Knox, and Schacht, 2007).

Sociology includes three major theoretical perspectives: the functionalist perspective, the conflict perspective, and the symbolic interaction perspective (sometimes called the interaction perspective, or simply the micro view). Each perspective offers a variety of explanations about the social world and human behavior.

\section{a. Functionalist Perspective}

The functionalist perspective is based largely on the works of Herbert Spencer, Emile Durkheim, Talcott Parsons, and Robert Merton. According to functionalism, society is a system of interconnected parts that work together in harmony to maintain a state of balance and social equilibrium for the whole.

\section{b. Conflict Perspective}

The conflict perspective views society as composed of different groups and interest competing for power and resources. The conflict perspective explains various aspects of our social world by looking at which groups have power and benefit from a particular social arrangement.

c. Symbolic Interaction Perspective

Symbolic interactionism reflects the micro-sociological perspective, and was largely influence by the work of early sociologists and philosophers, such as George Simmel, Charles Cooley, George Herbert Mead, and Erving Goffman. Symbolic interactionism emphasizes that human behavior is influenced by definitions and meanings that are created and 
maintained through symbolic interaction with others.

\section{RESEARCH METHOD}

\section{Research Design}

This is a descriptive qualitative research. It is a research design part of qualitative method that allows the researcher to describe a phenomenon by presenting the facts in rich detail without attempting to interpret them. Qualitative research is done without give priority in numbers, but focus on the deep understanding to interaction between concepts that is analyzed (Semi, 2012: 28). It is means that the qualitative research focuses on the understanding in the concept of the research.

Researcher who using qualitative research adapt a person- centered and holistic perspective to understand the human experience, without focusing on specific concepts. The original context of the experience is unique, and rich knowledge and insight can be generated in depth to present a lively picture of the participants' reality and social context. Researcher used this describe about moral value in short story The Last Leaf.

\section{A. Technique of Collecting the Data}

According to Widoyoko (2012:33) in collecting the data of the data of this researcher was intended to get data, explanation, facts, and accurate information's. The purpose of collecting the data is it found the data and get information about researcher. In collected data, the researcher used descriptive qualitative method.

The primary of the data this research The Last Leaf short story and researcher took two types of data from some reference and book. In relation to literature and moral value for support the subject matter. To get information about analyzed fiction the researcher found out some article from internet that explained about how to analyze fiction.

\section{B. Technique Of Analyzing The Data}

After collecting data, the researcher started to analyze the data. The researcher an analyzed the moral value in short story The Last Leaf applying sociological theory by Mooney, Knox, and Schacht (2007).

The primary steps reading and understanding The Last Leaf short story. In this case, the researcher reads short story The Last Leaf. After that, the researcher analyzing using sociological theory and find moral value in short story The Last Leaf. And the last conclude for getting the result.

\section{FINDINGS AND DISCUSSION}

The research has descriptive qualitative which analyzed about moral value in The Last Leaf short story. In this chapter, the research would like to presented the analyzed of moral value in The Last Leaf short story. The researcher would like to explain the entire moral value that find from in The Last Leaf by using sociological theory. 
The Last Leaf, short story by O. Henry, published in 1907 in his collection The Trimmed Lamp and Other Stories.

\section{a. The analysis of Moral Value in "The Last Leaf" short story based on using Sociological Theory}

Sociology includes three major theoretical perspectives: the functionalist perspective, the conflict perspective, and the symbolic integrationist perspective (sometimes called the integrationist perspective, or simply the micro view). Each perspective offers a variety of explanations about the social world and human behavior (Mooney, Knox, and Schacht, 2007).

In analyzing the moral value in short story The Last Leaf. The researcher used the definition expert moral value is described in his journal. In this chapter, the researcher analyzed some moral value in The Last Leaf:

1. The perspective of functionalist

According to Robert King Merton (1910-2003), the functionalist perspective is society is a functioning unit, with each part related to the whole. Whenever we examine a smaller part, we need to look for it functions and functions to see how it is related to the larger unit. This basic approach can be applied to any social group, whether an entire society, a college, or even a group as small as a family.

From the short story, the researcher find the functionalist perspective moral value find in short story The Last Leaf is:

- $\quad$ Second statement 1 is:

Be fair is being fully separable from human well-being, we are faced with the prospect of morally "right" actions and social systems that are, on balance, detrimental to the welfare of everyone affected by them (Harris, 2010: 55).

One morning the busy doctor invited Sue into the hallway (p.2)

The above condition is a functionalist perspective on the macro sociological approach. In The Last Leaf's short story, the doctor spends his busy time helping Sue in the hallway. Because a doctor still has to be fair to others to help even though he is busy. The moral value that sees from the side of caring among each other is justice, which is fair in dividing his busy time because of the many activities.

- $\quad$ Third statement 2 is:

Kind-hearted is having sympathetic nature: Humane, compassionate. Kindheartedness is the quality or state of being kindhearted (Webster,1981: 1243). From the short story is:

'Vass!' he cried. 'Is dere people in de world mit der foolishness to die because leafs dey drop off from a confounded vine? I haf not heard of such a thing. No, I vill not bosed as a model for your fool hermitdunderhead. Vy do you allow don't 
silly pusiness to come in dear prain of her? Ach, dot poor little Miss Yohnsy.' (p.6)

'She is very ill arid weak,' said Sue, 'and the fever has left her mind morbid and full of strange fancies. Very well, Mr. Behrman, if you do not care to pose for me, you needn't. But I think you are a horrid old - old flibberti-gibbet.'

'You are just like a woman!' yelled Behrman. 'Who said I vill not bosed? Go on. I come mit you.(p.7)

The researchers determine the moral value of the short story The Last Leaf based on sociological theory there is a functional structural perspective. The short story shows that even though he was angry, he still wanted to help Sue to help his business. Moral values can be taken as kindness, sympathetic feelings to someone who is sick.

- $\quad$ Fourth statement 3 is:

Being responsible is to have control and authority over something or someone and the duty of taking care of it or them (Walter, 2008). From the short story The Last Leaf is:

'Even chances,' said the doctor, talking Sue's thin, shaking hand in his. 'With good nursing you'll win.(p.9)

And

The next day the doctor said to Sue: 'She's out of danger. You've won. Nutrition and care now - that's all.' (p.9)
From the explanation of the story above that the researcher found a functionalist perspective. In the story, sue increasingly thin and trembling hands caring for johnsy turned out to be successful in making things better. The doctor also said that sue had won johnsy's silly mind. And the doctor said that Johnsy just needed better care and nutrition.

\section{The Conflict perspective}

According to Karl Max, the conflict perspective is the dominance of men over women was once considered natural and right. Symbolic interactionism emphasizes that human behavior is influenced by definitions and meanings that are created and maintained through symbolic interaction with others

From the short story, the researcher find of the conflict perspective in moral value The Last Leaf, This value are:

- $\quad$ The statement 4 is:

Old Behrman, with his red eyes plainly streaming, shouted his contempt and derision for such idiotic imaginings.

'Vass!' he cried. 'Is dere people in de world mit der foolishness to die because leafs dey drop off from a confounded vine? I haf not heard of such a thing. No, I vill not bosed as a model for your fool hermitdunderhead. Vy do you allow don't silly pusiness to come in dear prain of her? Ach, dot poor little Miss Yohnsy.' (p.6) 
'She is very ill arid weak,' said Sue, 'and the fever has left her mind morbid and full of strange fancies. Very well,(p.7)

From the short story above is a conflict perspective, where old Behrman was angry when he stated that Johnsy thought his life depended on the last leaf to fall. Sue also explained that Johnsy's mind was very chaotic.

From this statement we can draw the conclusion that moral values is be optimistic in living life, death is not only from disease.

- The statement 5 is:

'It is the last one,' said Johnsy. 'I thought it would surely fall during the night. I heard the wind. It will fall to-day, and I shall die at the same time.'

'Dear, dear!' said Sue, leaning her worn face down to the pillow; 'think of me, if you won't think of yourself. What would I do?'

But Johnsy did not answer. The lone something in all the world is a soul when it is making ready to go on its mysterious, far journey (p.8)

From the short story, researchers found conflicting perspectives from short stories, researchers found that Johnsy thought he would die when old grape leaves fell at night. But Sue tries to make sure that that won't happen and Johnsy is silent without a word. The moral value contained in the statement is that contradictions sometimes make the problem complicated, so solve the problem and make sure that bad thinking does not happen to him.

3. The symbolic integrationist perspective

Symbolic integrationist such as G.H. Mead (1863-1931) and C.H. Cooley (1846-1929) concentrate upon the interaction between individuals and groups. They note that people interact mainly through symbols, which include signs, gestures, and most importantly, through written and spoken words.

From the short story, the researcher found the symbolic integrationist perspective in The Last Leaf short story. This moral value was found in the short story is:

- The statement 6 is:

'She arranged her board and began a pen-and-ink drawing to illustrate a magazine story. Young artists must pave their way to Art by drawing pictures for magazine stories that young authors write to pave their way to Literature. (p.3)

As Sue was sketching a pair of elegant horseshow riding trousers and a monocle on the figure of the hero, an Idaho cowboy, she heard a low sound, several times repeated. She went quickly to the bedside. (p.3)

Johnsy eyes were open wide. She was looking out the window and counting - counting backward.(p.3)

Twelve,' she said, and a little later, 'eleven'; and then 'ten,' and 'nine'; and then 'eight' and 'seven,' almost together. Sue looked 
solicitously out the window. What was there to count? There was only a bare, dreary yard to be seen, and the blank side of the brick house twenty feet away. An old, old ivy vine, gnarled and decayed at the roots, climbed half-way up the brick wall. The cold breath of autumn had stricken its leaves from the vine until its skeleton branches clung, almost bare, to the crumbling bricks. (p.3)

From the statement above, the researcher found a symbolic perspective on moral values is when a young artist arranges his board to be illustrated with a pen and ink to make a magazine. When the young artist who arranged it was still sketching, he heard a low voice and came to him, apparently the sound of Johnsy saw and counted old ivy leaves falling from their branches and falling on collapsed bricks. we can conclude That statement of moral values in this perspective see what someone is doing in his work and patiently face the situation around him.

- $\quad$ The statement 7 is:

'Oh, I never heard of such nonsense,' complained Sue, with magnificent scorn. 'What have old ivy leaves to do with your getting well? And you used to love that vine so, you naughty girl. Don't be a goosey. Why, the doctor told me this morning that your chances for getting well real soon were - let's see exactly what he said - he said the chances were ten to one! Why, that's almost as good a chance as we have in New York when we ride on the street-cars or walk past a new building (p.4.)

In the above statement the researcher found a symbolic integrationist perspective. The moral value is the belief that a doctor believes that patients who experience a fairly severe illness can recover. Sue believes Johnsy will recover if he listens to the doctor's words and doesn't think silly things. That the conclusion of moral values that we can apply in life, anything that becomes a belief must be cultivated and realized in order to be happy in yourself and others.

- $\quad$ The statement 8 is:

'I have something to tell you, white mouse,' she said. 'Mr. Behrman died of pneumonia today in hospital. He was ill only two days. The janitor found him on the morning of the first day in his room downstairs helpless with pain. His shoes and clothing were wet through and icy cold. They couldn't imagine where he had been on such a dreadful night. And then they found a lantern, still lighted, and a ladder that had been dragged from its place, and some scattered brushes, and a palette with green and yellow colour mixed on it, and - look out the window, dear, at the last ivy leaf on the wall. Didn't you wonder why it never fluttered or moved when the wind blew? Ah, darling, it's Behrman's masterpiece - he painted it there the night that the last leaf fell.'(p.8) 
From the explanation of the above statement, the researcher found the sociological approach in the perspective of symbols was an extraordinary masterpiece created by Behrman. Sue's honesty about what happened on the last page. Honesty of a friend who makes johnsy excited because the last leaf does not fall.

Researchers concluded that there is value in The Last Leaf's sociological theory in kinds of moral values in the short story, namely tolerance, justice, trust, kindness, honesty, responsibility.

\section{CONCLUSION AND SUGGESTION}

\section{Conclusion}

After finding the moral values of the short story The Last Leaf by $\mathrm{O}$ Henry, used sociological theory approach in perspective, the researcher find six moral values that contain on The Last Leaf short story. The researcher can conclude that:

1. The moral values found in the short story The Last Leaf are tolerance, fairness, belief, kindhearted, honesty and responsibility.

2. By using the sociological approach, based on the perspective of as follow: functionalism, symbol, conflict. The researcher found out several moral values are tolerance, fairness, belief, kind-hearted, honesty, Responsibility in The Last Leaf. Because the story in often shows how to think positively about what is happening in our lives.

3. The moral values find in The Last Leaf of this short story have many moral values in our lives. Therefore, we as short story readers can find out what moral values contained in the story

4. Moral values in The Last Leaf short story is not to be pessimistic about what happened to us. Always instill positive and optimistic thoughts that all will be well.

\section{Suggestion}

The researcher hopes that this research will be helpful for the readers, who wanted to know about moral value. In fact, it will be better for the reader to understand about literature before reading a short story. Since that short story is one of familiar literary works to anyone. Short story can be enjoyed by anyone at any age with suitable short story genres. Moreover, it is also important to understand the moral values in story. Moral values make the reader application in lives.

\section{REFERENCES}

Bee. 1975. The Introduction of Morality. Boston. 287-289.

Bertens, K. 2005. Etika. Jakarta: Gramedia Pustaka Utama.

Burton, Jeremy. 2014. Read Literature. (https://www.quora.com/, Downloaded on 07th May 2017) 
Eagleton, Terry. 2003. Literary Theory: An Introduction, Second Edition. USA: The University of Minnesota Press.

Earle,William James.(1992). Introduction to Philosophy. New York: Mc. Graw Hill.

Endraswara, Suwardi. 2008. Metode Penelitian Psikologi Sastra. Yogyakarta: MCdPrCSS 2011. Metodologi Penelitian Sastra. Yogyakarta: UGM Press

Diyanni, Robert. (2001). Literature ( Reading Fiction, Poetry, and Drama Compact Edition). Singapore : McGraw- Hill International Edition.

Harris, Sam. 2010. The Moral Landscape, "How Science Can Determine Human Values." New York: Free Press.

Henry, O. (1907). The Last Leaf. collection The Trimmed Lamp and Other Stories.

Hornby.A S (2010). Oxford Advanced Learner's Dictionary. London: Oxford University Press.

Hurlock, Elizabeth B. 1997. Child Development, Sixth Edition. Me Graw:. Hill Book Company: Me Graw.

Irshad, Ayesha \& Ahmed, Mumtaz: The Structural Analysis of "Take Pity": A Short Story By Bernard Malamud, Vol. 2, No. 1, 2015, European Journal Of English Language, Linguistics And Literature university Of
Sargodha Women Campus, Faisalabad,Pakistan.

Kusmiyati, Anis. 2014. An Analysis of Moral Values in Ahmad Fuadi's Novel Rantau 1 Muara. Un Published Thesis, Wijaya Putra University W, Rizha \& Bejo:. March(2018). The Moral Values In "Chicken Run" Movie. Hal 92-93 Vol. 03, Number 01, March 2018, published JELL STIBA IEC Jakarta.

Kenney, William. (1966). How to Analyze Fiction. United State of America : Monarch Press.

Louden, Robert. B. 1992. Morality and Moral Theory. New York: Oxford University Press

Nurgiyantoro, Burhan. 2010. Teori Kajian Fiksi. Yogyakarta: Gadjah Mada University Press.

Risdianto, Faizal. 2011. An Introduction of Literature. Yogyakarta: Trus Media Publishing.

Rokhmansyah, A., 2013. Study dan Pengkajian Sastra (Perkenalan Awal Terhadap Ilmu Sastra).Semarang: GrahaIlmu.

Robert, Frost. 2014. Moral Values in Education.

(https://www.quora.com/, Instructor and Flight Controller at NASA, Download on 07th May2017)

Sartre, Jean Paul. 1949. What Is Literature. New York: Philosophical Library. 
Semi, M. A., 2012. Metode Penelitian Sastra. Bandung: Angkasa Bandung.

Schwartz ,S. H.and Boenke.K. 2004. Jurnal of Research in Morality. Canada: McGill University. 230-253

Shaw, V. (1983) The Short Story. London: Longman

Syah ridho, ahmad (2016). plot analysis of friends forever short story by aditi das bhowmik. un published thesis, Universitas pasir pengaraian.

Susanti, Dani A. 2012. An Analysis of Moral Values taken from Edensor Novel by Andrea Hirata. Un Published Thesis, STAIN Salatiga.

Walter, Elizabeth. 2008. Cambridge Advanced Dictionary. Cambridge: Cambridge University Press.

Webster.(1981). Third New International Dictionary, Encyclopedia Britania, Meriam Webster Inc. 